\title{
Nutritional Status Assessment in Children and Adolescents with Various Levels of Physical Activity in Aspect of Obesity
}

\author{
Jerzy Słowik ${ }^{a} \quad$ Elżbieta Grochowska-Niedworok ${ }^{b} \quad$ Izabela Maciejewska-Paszek $^{c}$ \\ Marek Kardas $^{b} \quad$ Ewa Niewiadomskad $^{d}$ Magdalena Szostak-Trybuśc \\ Maria Palka-Słowik ${ }^{a}$ Tomasz Irzyniec ${ }^{c}$ \\ aprivate Medical Practice "Familia", Siemianowice Slaskie, Poland; b Department of Dietetics, School

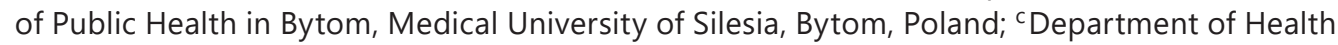 \\ Promotion and Community Nursing, School of Health Sciences, Medical University of Silesia, \\ Katowice, Poland; ${ }^{d}$ Department of Epidemiology and Biostatistics, School of Public Health in \\ Bytom, Medical University of Silesia, Bytom, Poland
}

\section{Keywords}

Obesity · Nutritional status · Physical activity

\section{Abstract}

Introduction: A rational way of nourishment, combined with adequate physical activity, are the basic components of maintaining proper body condition. Objective: The aim of the study was to evaluate nutritional status among children and adolescents with different levels of physical activity. Methods: The study group consisted of 1,013 students of both genders aged between 7 and 18 years attending elementary and post-primary schools (general and sports profile) in Siemianowice Slaskie. Results: The crude body mass index (BMI) values ranged from 12.78 to 35.3 . Body mass within the limits of arbitrary standard referred to $70 \%$ of the examined group, overweight or obesity was found in over $25 \%$. Percentage of body fat (FATP) values ranged from 5.7 to $45.2 \%$. Conclusions: A significant number of children and adolescents were overweight or obese based on BMI categories and FATP values. Overweight and obesity were most common among younger children, particularly boys. Higher torso FATP levels were more common among sports-oriented class students. BMI is not a good tool for the determination of the nutritional status of children and adolescents, while the bioelectric impedance method enables one to conduct a precise analysis of adipose tissue content and location. Sports-oriented elementary school students from the study group were characterized by higher FATP values. 


\section{Introduction}

According to the available research results, health-promoting behavior accounts for nearly half of the factors responsible for good condition of the body. The fundamental components of a healthy lifestyle include: rational nutrition, physical activity, a stable emotional state, and a sufficient amount of sleep. The most common lifestyle errors among children and adolescents include inappropriate nutrition and insufficient physical activity [1-6].

Physical activity and appropriate nutrition are of key importance to health [7]. The definition of physical activity includes all actions involving muscle work causing energy expenditure that is higher than during rest. Regular physical activity matched to one's abilities has a positive impact on the development of children and adolescents and maintains good health by acting on all body systems. Systematic physical activity with a gradually increased load and high stimulus variability improves body fitness and increases resistance to negative physical and psychological factors [8]. Physical activity undertaken regularly in childhood results in healthy lifestyle habits in adulthood. Both the lack of physical activity and its excess have a negative effect on the nutritional status. The most common nutritional abnormalities include undernourishment as well as overweight and obesity [9].

In the last decades, overweight and obesity have been dubbed the pandemic of the 21st century. Obesity is a complex, multifactor disease; however, the underlying cause is usually a poor diet. Excess body weight is increasingly commonly observed in children and adolescents of all ages. Currently, a large number of studies are being conducted in order to determine the risk factors for excess weight and methods of its identification [10,11].

Nutritional status is an important indicator enabling diagnosis [9]. Nutritional status is assessed using anthropometric and biochemical tests, among others. Anthropometric measurements used to determine nutritional status include the assessment of the physiological status of the body based on its height and weight.

Body mass index (BMI) is the most popular and common method for nutritional status assessment. BMI is uncomplicated in terms of calculation; however, it does have certain flaws: primarily, it does not provide any information on body mass composition (body fat, muscle tissue, and water content). Therefore, a result showing overweight or obesity in individuals with highly developed musculature is often incorrect.

In the case of children, the interpretation of BMI is very difficult due to the rapid growth and development of the body. In order to compare a BMI value with the norm, it is recommended that BMI standard deviation $z$-score $\left(z_{\mathrm{std}}\right)$, age, and gender be considered $[12,13]$.

Another method is bioelectric impedance analysis (BIA), which involves measurements with an electric current flowing through the water and fat components of the body [14-17]. The bioelectric impedance method is a noninvasive, painless, and quick method (the procedure lasts between a few seconds to a few minutes). Due to its easy availability, low cost, and the possibility of frequent repetition, BIA is considered by many researchers to be the most objective method for the assessment of nutritional status, including that of children. It allows for indirect calculation of the total water content, adipose tissue mass, and lean body mass. Body mass composition differs to a large extent between children and adults. During growth, the components which change to the most extent are water content and lean body mass (bone mineral content). Body mass composition analysis using the BIA method is usually conducted in a tetrapolar fashion using 4 leads: two electrodes on the hands and two electrodes on the feet.

The parameters used in BIA to assess body mass composition are usually fat-free mass (FFM) and fat mass. FFM primarily includes the weight of muscle tissue, bone tissue, internal organs, and bodily fluids. Fat mass mainly includes lipid components of the body. In chemical 
terms, FFM is composed primarily of water (72-74\%) and electrolytes. FFM can have various values depending on the age and gender of the subjects. FFM anomalies are associated mainly with an increase or decrease in muscle tissue mass. The FFM value is usually measured in percentages or kilograms.

Health hazards associated with excessive body mass and poor eating habits are the subject of many scientific publications. The aim of the present study was to identify overweight and obesity in children and adolescents with various levels of physical activity by assessing their nutritional status using two methods. Due to the lack of adipose tissue norms for Polish children, the current study pays particular attention to the percentage of body fat in the subjects.

\section{Methods}

The study was conducted upon the consent of the institutional review board of the Medical University of Silesia in Katowice (KNW 0022/KB1/73/I/16). The subjects' parents and managers of schools in which the study was conducted provided their written consent. The study was conducted between September 2016 and May 2017. The study group included 1,013 students of both genders aged 7-18 years attending schools of different stages (elementary or high schools) and types (general or sports-oriented). Students from general classes did not undertake any additional physical activity beyond the obligatory physical education lessons. Students from sports-oriented classes, as well as attending obligatory physical education lessons, practiced their chosen sport (swimming, volleyball, football).

The inclusion criteria were the following:

- attending elementary or high school in the city of Siemianowice Slaskie, Poland (general or sports-oriented),

- age 7-18 years,

- parents' or guardians' consent to participation in the study,

- presence at school on the day of the study.

The study group was divided according to gender ( 485 girls, 528 boys). In the study, the division according to the type of the students' school was taken into account: general (216) and sports-oriented (797). The subjects were divided into 9 age groups.

In order to achieve the main goals of the study, the subjects' nutritional status was assessed. The height and weight of the subjects was measured in school disease prevention offices using a medical scale with a height meter (model WPT 60/150 OW). The results were the basis for the assessment of height-weight proportions relative to norms for the Polish population and WHO recommendations regarding height, weight, and BMI. The BMI analysis was conducted based on standardized values obtained using the LMS method according to WHO recommendations (underweight: $z_{\text {std }} \leq-2$, normal: $-2<z_{\text {std }} \leq 1$, overweight: $1<z_{\text {std }} \leq$ 2 , obese: $z_{\text {std }}>2$ ) [12]. Comparative analysis in groups was conducted based on standardized values with BMI categories (underweight, normal, overweight, obese).

Body mass composition was assessed using the bioelectric impedance method with the Tanita BC 418 MA device holding the certificate No. 93/42 EEC. The following components were calculated using the BIA method: percentage of body fat (FATP), percentage of body fat in the torso (TRFATP), and BMI.

The body composition monitor Tanita BC $418 \mathrm{MA}$ is equipped with a system of eight polar measuring electrodes, which allows for very precise calculations of fat and muscle tissue in different body segments (lower left extremity, upper left extremity, lower right extremity, upper right extremity, torso). The device generates a full body composition analysis within approximately $20 \mathrm{~s}$. It works with a $50-\mathrm{kHz}, 0.8-\mathrm{mA}$ current. 
The measurements were made according to the standard protocol set by the device manufacturer: in the morning, with an empty stomach, in underwear, without shoes or socks, with clean and dry feet. Since the level of hydration can affect the results, the subjects were instructed to avoid strenuous physical exertion and fluid intake before measurement.

The cut-off points provided in the Tanita BC 418 MA instruction manual were used to categorize body fat percentage values. Comparative analysis in groups was conducted based on raw values or FATP categories (underweight, normal, overweight, obese). Statistical calculations were conducted using an MS Excel spreadsheet, MS Office 2013, statistical package R 3.1.2 available under the GNU GPL license, and the STATISTICA 12, StatSoft Polska, software. Measurable data were characterized using the mean and standard deviation. The normality of the variable distribution was verified with the Shapiro-Wilk test. The significance of differences between means in the studied groups were checked using the Student $t$ test. In the case of skewed distributions, their consistency in groups was tested using the Mann-Whitney U test. Nominal data were expressed in percentages. The presence of relationships between nominal variables were verified with the $\chi^{2}$ test or the direct Fisher test for $\mathrm{n} \times \mathrm{m}$ tables $(\mathrm{n}, \mathrm{m} \geq 2)$ in the case of low numbers. The statistical significance level of $p<$ 0.05 was adopted.

\section{Results}

The results obtained are presented in Tables 1-3.

\section{Profile of the Study Group in Terms of BMI}

Table 1 presents the study group's BMI categorization with regard to age, gender, and school type according to the WHO scale. Approximately 724 studied children (71.5\%) were found to have a normal body mass according to BMI categories, while 269 individuals (26.6\%) were found to be overweight or obese. Abnormalities (underweight, overweight, obesity) were more common in boys $(33.5 \%)$ than in girls (23.1\%). Underweight was most common in children aged 10-12 years (3.4\%). Overweight and obesity was found in younger children aged $7-9$ years and $10-12$ years $(17.3 \%)$.

\section{Body Fat Content}

Table 2 presents the profile of the study population in terms of FATP with regard to age, gender, and school type. Normal body mass in terms of the percentage of body fat was found in 672 of subjects (66.3\%), while 305 individuals (30.1\%) were found to be overweight or obese (Table 2). Abnormalities (overweight, obesity) were more common in boys than in girls. Underweight was most common in subjects aged 16-18 years. Overweight and obesity was most commonly found in younger children aged 7-9 years and 10-12 years.

\section{Percentage of Body Fat in the Torso in the Study Group}

Table 3 presents percentages of TRFATP with regard to school type, age, and gender of students who took part in the study. In the groups of girls aged 6-7 years and boys aged 6-7 years and 13 years, significantly higher TRFATP values were found in sports-oriented classes compared to general classes. 

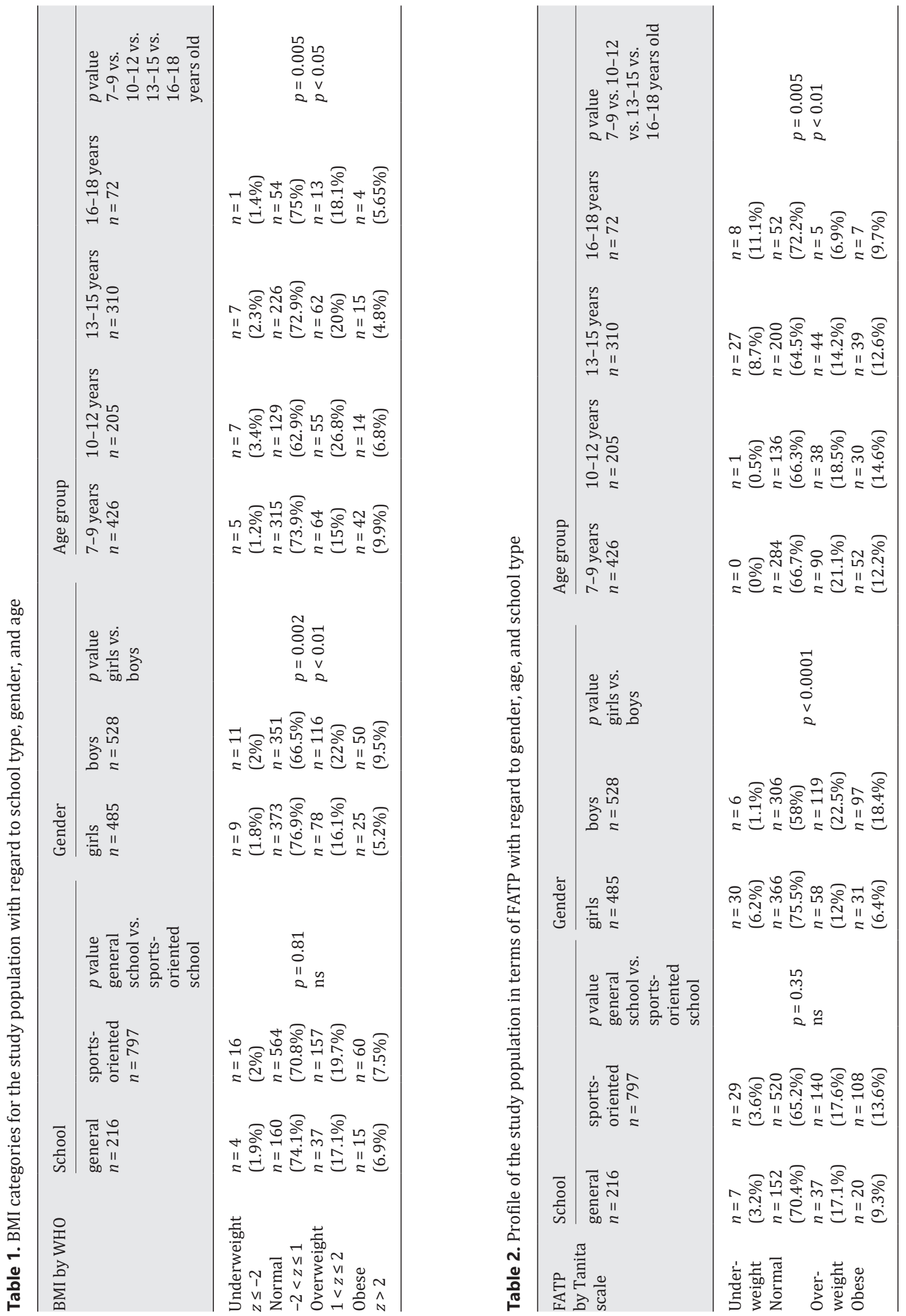

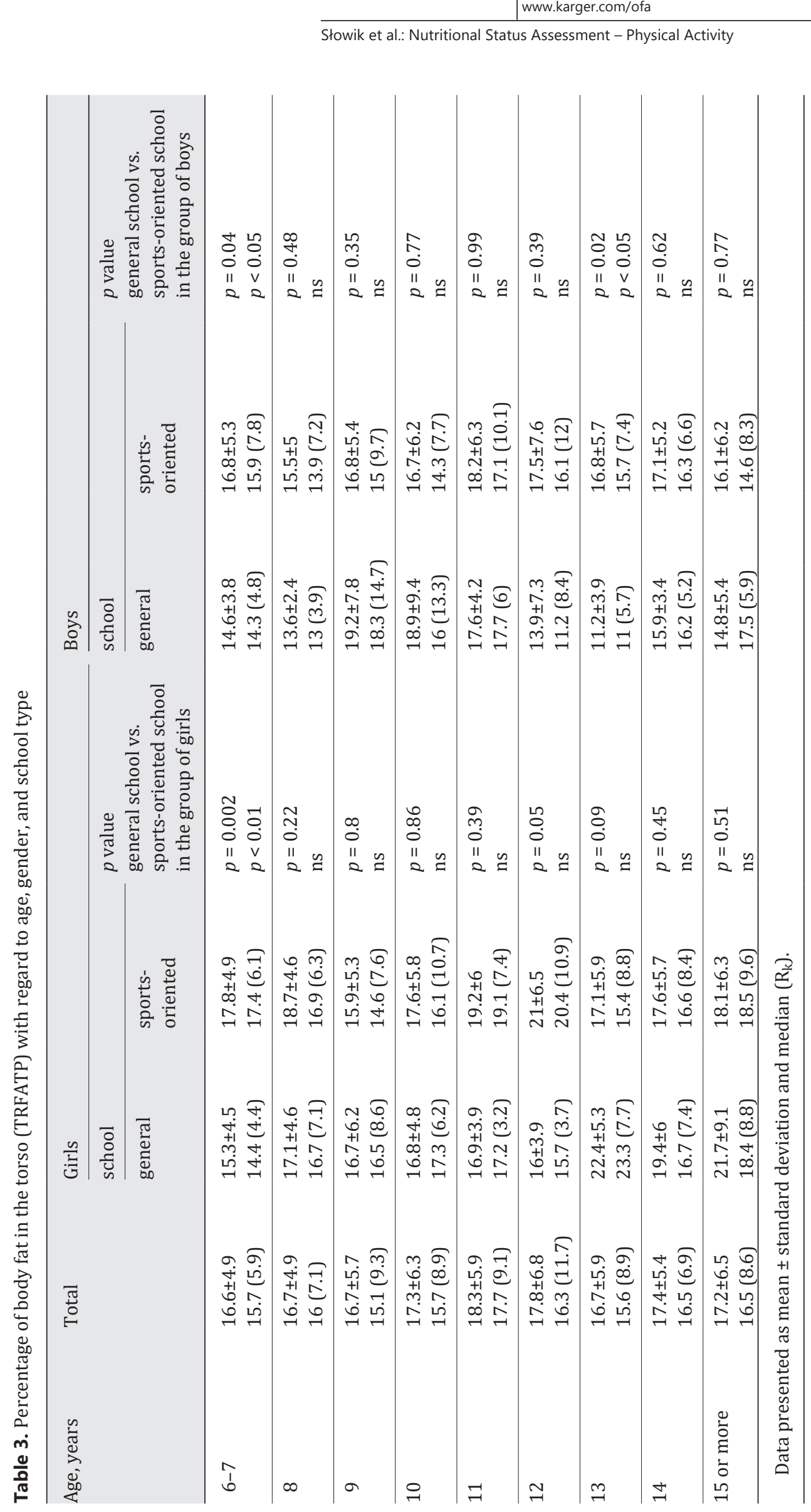
Słowik et al.: Nutritional Status Assessment - Physical Activity

\section{Discussion/Conclusion}

In the presented study, BMI, selected body mass components, and nutritional status have been analyzed. In total, overweight was found in 194 subjects (19.2\%) and obesity in 75 subjects $(7.4 \%)$.

In the HBSC study (Health Behaviour in School-aged Children) conducted in 2002-2010, which included a population of Danish children and adolescents (16,557 subjects), the prevalence of overweight was found to range between 9.9 and $18.5 \%$, while obesity from 1.9 to $4.4 \%$ [18]. In 2008, Martin et al. [19] estimated the prevalence of overweight and obesity to be 22.9\%. Research by the National Food and Nutrition Institute in Poland indicated that children and adolescents in Poland are gaining weight at the highest rate in Europe [20]. Over the last 20 years, the percentage of overweight and obese children has increased threefold. Data from 2013 published by the National Food and Nutrition Institute regarding overweight and obesity in different Polish provinces confirmed the highest number of cases of excess weight to be present in the Mazovia province (32\%) and the lowest one in the Silesia province $(16.5 \%)$. The current study has confirmed the presence of overweight and obesity in $26.6 \%$ of subjects.

Rodd and Sharma [21], who analyzed a population of Canadian children in 2004-2013 $(14,014$ subjects aged from 3 to 19 years), confirmed a decrease in the prevalence of overweight and obesity from 30.7 to $27 \%$. Ogden et al. [22], who analyzed the prevalence of obesity in the pediatric population of the United States in 1988-1994 and 2013-2014 (40,780 children and adolescents aged from 2 to 19 years), found that between 2011 and 2014, the prevalence of obesity in 2- to 19-year-olds in the USA was approximately $17 \%$. In the group of 6- to 11 -year-olds, obesity was present in $17.5 \%$ of cases, while in 12 - to 19 -year-olds, it was found in $20.5 \%$ of subjects [22]. As many as $32.2 \%$ of the studied children and adolescents were found to be overweight and $17.3 \%$ obese in another study including a population of children in the United States $(26,690$ children and adolescents aged between 2 and 19 years, 2011-2012) [23]. Therefore, considering the above data and the results of the present study, one may conclude that the prevalence of overweight and obesity in the population of children and adolescents in the present study is similar than that of the pediatric population of other Western countries.

Furthermore, it has been concluded that nutritional status abnormalities resulting in overweight and obesity were more common in boys (overweight in $22 \%$, obesity in $9.5 \%$ ) than in girls (overweight in 16.1\%, obesity in 5.2\%). Pyrżak et al. [24] obtained similar results in a study on children from the Mazovia province, Poland, including 541 students aged 7-9 years. It was demonstrated that mean BMI values were higher in boys, both among 7- to 8and 9-year-olds. Falkowska et al. [25] arrived at the same conclusions. They found $31 \%$ of boys and $23 \%$ of girls aged from 10 to 12 years to be overweight or obese. In terms of somatic features analysis (sexual dimorphism), Napierała et al. [26] found higher BMI values among boys in a group of 1,115 children from the city of Bydgoszcz, Poland. Mazur et al. [27], who studied children in the south-eastern part of Poland (2,182 boys, 2,066 girls), found $13.3 \%$ of girls and $14.2 \%$ of boys to be overweight and $7.7 \%$ of girls and $6.4 \%$ of boys to be obese. Fleming et al. [28] demonstrated that $23.8 \%$ of boys and $22.6 \%$ of girls in developed countries were found to be overweight or obese. However, in Swiss students, $11.8 \%$ of boys and $11.9 \%$ of girls were found to be overweight, while $7.5 \%$ of boys and $5.7 \%$ of girls were diagnosed with obesity [29].

In terms of age, the majority of cases of overweight were observed in the group of subjects aged from 10 to 12 years $(26.8 \%)$, while obesity was most common in 7 - to 9-year-olds (9.9\%). A study conducted by Bilewicz-Wyrozumska et al. [30], which included 3,601 children from the Silesia voivodship, demonstrated that BMI values in girls aged between 10 and 11 
years were usually higher than those observed in boys, while in the group of 14- to 18-yearolds, there was an opposite tendency.

Overweight and obesity are diet-related disorders most commonly diagnosed based on BMI values. However, many researchers confirm that BMI should not be the only parameter used to determine the presence of overweight or obesity since it does not correlate strictly with body fat content [31]. The presence of a normal BMI value and high body fat content has been increasingly common; individuals with such parameters are referred to as "skinny fat" in popular science sources [32]. An increased amount of adipose tissue is usually accumulated in the torso in such cases. Therefore, the evaluation of the relationship between BMI and the percentage of body fat is key to the diagnosis of overweight and obesity.

In the present study, normal body mass in terms of FATP was found in $66.3 \%$ of the students and overweight and obesity were found in $30.1 \%$ of the subjects. No uniform norms have been developed for the percentage of body fat in children and adolescents (percentile charts for the Polish population).

In a study by Schwandt et al. [33] regarding body fat content in German children, it was found that girls are significantly more likely to have higher adipose tissue content. The percentage of body fat in boys ranged between 11.7 and $14.3 \%$, and in girls between 13.3 and $23.1 \%$. Bailey-Davis et al. [31] studied a group of 413 children, analyzing their BMI values, the percentage of body fat, and eating preferences. They found the mean body fat content in the group to be $22.9 \%$. The percentage of body fat in the study population ranged between 20.8 and $28.5 \%$ in girls and between 13 and $24.3 \%$ in boys. Khadilkar et al. [34] aimed at developing percentile charts for body fat content in children. They proposed cut-off values for girls aged 6-7 years (overweight: 85 th percentile, $26 \%$ body fat content; obesity: 95 th percentile, $35 \%$ body fat content) and girls aged 13 (overweight: 85 th percentile, $44 \%$ body fat content; obesity: 95th percentile, $48 \%$ body fat content). In addition, Khadilkar et al. [34] proposed the following values for 13 -year-old boys: overweight: 85 th percentile, $30 \%$ body fat content; obesity: 95th percentile, $49 \%$ body fat content.

A representative study on a population of Korean children $(1,579$ subjects in total, including 834 boys and 745 girls) conducted by Kim et al. [35] led to the development of tables and percentile charts for the percentage of body fat in children and adolescents aged from 10 to 18 years. The norm for the percentage of body fat in 13-year-old boys was $24.2 \%$, while for 13-year-old girls, the figure adopted was $30.7 \%$.

In the present study, the observed values were lower. Therefore, it can be concluded that percentile charts for the percentage of body fat should be developed separately for different populations. The analysis of the level of physical activity in the present study did not reveal any relationship between the type of school (general vs. sports-oriented) and the prevalence of overweight and obesity determined based on BMI. It was concluded that increased physical activity does not contribute to a significant decrease in BMI and FATP. This is probably due to a badly balanced diet and poor eating habits, which preclude the achievement of the right nutritional status. However, a study by Frączek et al. [36] demonstrated a lower rate of excess weight in children and adolescents undertaking intense physical activity.

A study by Marcysiak et al. [37] on a population of students from sports-oriented and general classes in the town of Ustrzyki Dolne, Poland, confirmed the lack of influence of class type on eating habits and the level of physical activity. In turn, in the presented study, in students aged 6-7 years attending a sports-oriented school, significantly higher percentages of body fat in the torso were found, despite normal BMI values.

In conclusion, poor nutritional status as well as elevated FATP and TRFATP values are found both in students leading a sedentary lifestyle outside of school activities and those undertaking increased levels of physical activity. Therefore, preventive measures to promote a healthy lifestyle would be recommended, including primarily the principles of healthy 
eating (introduction of correct eating habits both at school and at home) and appropriate levels of physical activity. This will help prevent the development of overweight and obesity among children and adolescents.

\section{Statement of Ethics}

The study was conducted upon the consent of the institutional review board of the Medical University of Silesia in Katowice (KNW 0022/KB1/73/I/16).

\section{Disclosure Statement}

The authors have no conflicts of interest to declare.

\section{Funding Sources}

None.

\section{Author Contributions}

J.S., E.G.-N., M.K. designed the study and were involved in data interpretation. I.M.-P., M.S.-T., M.P.-S. conducted children measurements and data collection. E.N. analyzed the data. T.I. was involved in study implementation. All authors were involved in writing the paper and gave final approval of the submitted and published versions.

\section{References}

1 Bég SA, Hauser ME. Proactive Living: A Unique Model for the Promotion of Lifestyle Medicine. Am J Lifestyle Med. 2017 Jun;11(6):440-2.

2 Hashemi N, Sebar B, Harris N. The relationship between cultural capital and lifestyle health behaviours in young people: a systematic review. Public Health. 2018 Nov;164:57-67.

3 Amireault S, Fong AJ, Sabiston CM. Promoting Healthy Eating and Physical Activity Behaviors: A Systematic Review of Multiple Health Behavior Change Interventions Among Cancer Survivors. Am J Lifestyle Med. 2016 Aug;12(3):184-99.

4 Ortega FB, Cadenas-Sanchez C, Migueles JH, Labayen I, Ruiz JR, Sui X, et al. Role of Physical Activity and Fitness in the Characterization and Prognosis of the Metabolically Healthy Obesity Phenotype: A Systematic Review and Meta-analysis. Prog Cardiovasc Dis. 2018 Jul - Aug;61(2):190-205.

5 Radzimirska-Graczyk M, Chalcarz W. Development of children and school youth and sports activity. Nat Med. 2006;2:35-8.

6 Moon JR. Body composition in athletes and sports nutrition: an examination of the bioimpedence analysis technique. Eur J Clin Nutr. 2013 Jan;67 Suppl 1:S54-9.

7 Zota D, Dalma A, Petralias A, Lykou A, Kastorini CM, Yannakoulia M, et al. Promotion of healthy nutrition among students participating in a school food aid program: a randomized trial. Int J Public Health. 2016 Jun; 61(5):583-92.

8 Moshfegh AJ, Rhodes DG, Baer DJ, Murayi T, Clemens JC, Rumpler WV, et al. The US Department of Agriculture Automated Multiple-Pass Method reduces bias in the collection of energy intakes. Am J Clin Nutr. 2008 Aug; 88(2):324-32.

9 Verdich C, Barbe P, Petersen M, Grau K, Ward L, Macdonald I, et al. Changes in body composition during weight loss in obese subjects in the NUGENOB study: comparison of bioelectrical impedance vs. dual-energy X-ray absorptiometry. Diabetes Metab. 2011 Jun;37(3):222-9.

10 Sabin MA, Kiess W. Childhood obesity: current and novel approaches. Best Pract Res Clin Endocrinol Metab. 2015 Jun;29(3):327-38. 
Słowik et al.: Nutritional Status Assessment - Physical Activity

11 Morandi A, Maffeis C. Predictors of metabolic risk in childhood obesity. Horm Res Paediatr. 2014;82(1):3-11.

12 de Onis M, Onyango A, Borghi E. WHO Child Growth Standards Length/height-for-age, weight-for-age, weightfor-length, weight-for-height and body mass index-for age. Methods and development World Health Organization 2009. [Web page] http://www.who.int/childgrowth/standards/Technical_report.pdf?ua=1. Accessed September 21, 2018

13 Güngör NK. Overweight and obesity in children and adolescents. J Clin Res Pediatr Endocrinol. 2014 Sep;6(3): 129-43.

14 Johnson Stoklossa CA, Forhan M, Padwal RS, Gonzalez MC, Prado CM. Practical Considerations for Body Composition Assessment of Adults with Class II/III Obesity Using Bioelectrical Impedance Analysis or DualEnergy X-Ray Absorptiometry. Curr Obes Rep. 2016 Dec;5(4):389-96.

15 Verdich C, Barbe P, Petersen M, Grau K, Ward L, Macdonald I, et al. Changes in body composition during weight loss in obese subjects in the NUGENOB study: comparison of bioelectrical impedance vs. dual-energy X-ray absorptiometry. Diabetes Metab. 2011 Jun;37(3):222-9.

16 Kriemler S, Puder J, Zahner L, Roth R, Braun-Fahrländer C, Bedogni G. Cross-validation of bioelectrical impedance analysis for the assessment of body composition in a representative sample of 6- to 13-year-old children. Eur J Clin Nutr. 2009 May;63(5):619-26.

17 Talma H, Chinapaw MJ, Bakker B, HiraSing RA, Terwee CB, Altenburg TM. Bioelectrical impedence analysis to estimate body composition in children and adolescents: a systematic review and evidence appraisal of validity, responsiveness, reliability and measurement error. Obes Rev. 2013 Nov;14(11):895-905.

18 Schmidt Morgen C, Rokholm B, Sjöberg Brixval C, Schou Andersen C, Geisler Andersen L, Rasmussen M, et al. Trends in prevalence of overweight and obesity in danish infants, children and adolescents-are we still on a plateau? PLoS One. 2013 Jul;8(7):e69860.

19 Martin K, Rosenberg M, Pratt IS, Miller M, McCormack G, Giles-Corti B, et al. Prevalence of overweight, obesity and underweight in Western Australian school-aged children; 2008 compared with 2003. Public Health Nutr. 2014 Dec;17(12):2687-91.

20 Adamson P. UNICEF Report Card 11. Warunki i jakość życia dzieci w krajach rozwiniętych. Analiza porównawcza. [Web page]. file://C:/Users/User/Downloads/Warunki\%20i\%20jakość\%20życia\%20dzieci\%20 w\%20krajach\%20rozwiniętych.pdf. Accessed September 21, 2018.

21 Rodd C, Sharma AK. Recent trends in the prevalence of overweight and obesity among Canadian children. CMAJ. 2016 Sep;188(13):E313-20.

22 Ogden CL, Carroll MD, Lawman HG, Fryar CD, Kruszon-Moran D, Kit BK, et al. Trends in Obesity Prevelence among children and adolescents in the United States 1988-1994 through 2013-2014. JAMA. 2016 Jun; 315(21):2292-9.

23 Skinner AC, Skelton JA. Prevalence and trends in obesity and severe obesity among children in the United States, 1999-2012. JAMA Pediatr. 2014 Jun;168(6):561-6.

24 Pyrżak B, Majcher A. Rymkiewicz- Kluszyńska B. Częstość występowania nadwagi i otyłości u dzieci w wieku 7-9 lat województwa mazowieckiego. Endokrynol Ped. 2007;4(21):43-9.

25 Falkowska A, Stefańska E, Ostrowska L. Ocena sposobu żywienia dzieci w wieku 10-12 lat o zróżnicowanym stopniu odżywienia. Endokrynol Otył Zab Przem Mat. 2011;7(4):222-8.

26 Napierała M, Kuska M, Żukowska H, Szarak-Eckardt M, Żukow W. Dymorfizm płciowy cech somatycznych 14-16 letnich gimnazjalistów z wybranych gimnazjów w Bydgoszczy. J Health Sci. 2013;3(5):425-38.

27 Mazur A, Klimek K, Telega G, Filip R, Małecka-Tendera E. Ten-year secular trend of overweight and obesity in school children in south-eastern Poland. Ann Agric Environ Med. 2014;21(3):634-8.

28 Fleming M, Robinson T, Thomson M, et al. Global, regional and national prevalence of overweight and obesity in children and adults 1980-2013: A systematic analysis. Lancet. 2014;30(384):766-81.

29 Murer SB, Saarsalu S, Zimmermann J, Herter-Aeberli I. Risk factors for overweight and obesity in Swiss primary school children: results from a representative national survey. Eur J Nutr. 2016 Mar;55(2):621-9.

30 Bilewicz-Wyrozumska T, Lar K, Dul L, Król K, Mroczek A, Zbrojkiewicz E, et al. Analiza wskaźnika BMI u dzieci w województwie śląskim. Zdrowie i dobrostan 2015. Wydawnictwo Naukowe Neurocentrum; 2015. pp. 23-7.

31 Bailey-Davis L, Poulsen MN, Hirsch AG, Pollak J, Glass TA, Schwartz BS. Home Food Rules in Relation to Youth Eating Behaviors, Body Mass Index, Waist Circumference, and Percent Body Fat. J Adolesc Health. 2017 Mar; $60(3): 270-6$.

32 Zdrowo. Sport. Skinny fat - padradoks "chudego grubasa”. [Web page] https://zdrowo.pl/sport/skinny-fatparadoks-chudego-grubasa. Accessed September 21, 2018.

33 Schwandt P, von Eckardstein A, Haas GM. Percentiles of percentage body fat in german children and adolescents: an international comparison. Int J Prev Med. 2012 Dec;3(12):846-52.

34 Khadilkar AV, Sanwalka NJ, Chiplonkar SA, Khadilkar VV, Pandit D. Body fat reference percentiles on healthy affluent Indian children and adolescents to screen for adiposity. Int J Obes. 2013 Jul;37(7):947-53.

35 Kim K, Yun SH, Jang MJ, Oh KW. Body fat percentile curves for Korean children and adolescents: a data from the Korea National Health and Nutrition Examination Survey 2009-2010. J Korean Med Sci. 2013 Mar;28(3): 443-9.

36 Frączek B, Klimek AT. G. Cieślar G.: aktywność fizyczna jako element prozdrowotnego stylu życia rodziny. Ann Univ M Curie-Skłodowska. 2004;14(2):94-101.

37 Marcysiak M, Ciosek A, Żywica M, et al. Zachowania żywieniowe i aktywność fizyczna uczniów klas sportowych i ogólnych w Ustrzykach Dolnych. Probl Pielęg. 2009;17(3):216-22. 